\title{
U-РВ ИЗОТОПНЫЙ ВОЗРАСТ И ТЕКТОНИЧЕСКАЯ ПОЗИЦИЯ ПАЛЕОПРОТЕРОЗОЙСКИХ АНДЕЗИТОВЫХ ПОРФИРИТОВ КУРСКОГО БЛОКА ВОСТОЧНОЙ САРМАТИИ
}

\author{
С. В. Цыбуляев, К. А. Савко \\ Воронежский государственный университет \\ Поступила в редакцию 27 сентября 2018 г.
}

\begin{abstract}
Аннотация: одним из проявлений вулканитов в пределах Курского блока Восточной Сарматии являются андезитовые порфириты глазуновской свиты, вскрытые в пределах Никитовского участка одной скважиной 2926 на северном фланге Орловско-Тимской синформыл. Андезитовые порфириты характеризуются содержанием $\mathrm{SiO}_{2}=57-61 \%$ и повышенной магнезиальностью $(\mathrm{Mg} \#=0,45-0,62)$. Они относятся к метаглиноземистым калиево-натровым $\left(\mathrm{Na}_{2} \mathrm{O} / \mathrm{K}_{2} \mathrm{O}=1,1-3,2\right)$ породам. По соотношению $\mathrm{K}_{2} \mathrm{O}-\mathrm{SiO}_{2}$ порфириты являются высококалиевыми разностями щелочно-известковистой серии. Установлен возраст их формирования - $2067 \pm 5$ млн лет. При сопоставлении геохронологических данных и интерпретации дискриминантных диаграмм тектонических обстановок наиболее вероятным представляется формирование андезитовых порфиритов $в$ постколлизионной геодинамической обстановке.
\end{abstract}

Ключевые слова: Сарматия, Курский блок, геохронология, изотопный возраст, андезить, ичиркон.

\section{U-PB ISOTOPE AGE AND TECTONIC POSITION OF THE PALEOPROTEROSOIC ANDESITE PORPHYRITES, KURSK BLOCK, EASTERN SARMATIA}

\begin{abstract}
Kursk block of Eastern Sarmatia is the andesite porphyrites of the Glazunovka suite, opened by one well 2926 on the northern flank of the Oryol-Tim sinform. Andesitic porphyrites are content (SiO2 $=57-61 \%$ and increased magnesium $(\mathrm{Mg} \#=0,45-$ 0,62)). They belong to metaaluminous potassium-sodium (Na2O / K2O =1,1-3,2) rocks. According to the $\mathrm{K} 2 \mathrm{O}$ - SiO2 ratio, porphyrites are high-potassium alkali-calcareous series differences. The eruption age of Glazunovka suite andesite porphyrites from the Kursk block of East Sarmatia is determinated at 2067 $\pm 5 \mathrm{Ma}$. Our geochronological data and discriminant diagram interpretation suggest that eruption of the andesite porphyrites occured in post-collisional setting.
\end{abstract}

Key words: Sarmatia, Kursk block, geochronology, isotope age, andesites, zircon.

\section{Введение}

Палеопротерозойские вулканиты являются индикаторами геодинамических режимов континентальной коры Курского блока Восточной Сарматии (КБВС). Одним из таких проявлений является вулканическая породная ассоциация глазуновской свиты, вскрытая в пределах Никитовского участка одной скважиной 2926 на северном фланге Орловско-Тимской синформы (рис. 1).

Скважина 2926 была пробурена в 1972 году и помимо андезитов глазуновской серии, также вскрыла подстилающие их базальты. О причинах формировании базальт-андезитовой ассоциации было высказано несколько противоречащих друг другу версий. Одни исследователи объединяли породы среднего и основного состава в единую андезит-базальтовую формацию [1]. Другие выделяли две вулканические формации нижнепротерозойского возраста: трапповую и более позднюю андезитовую $[2,3]$, либо объединяли вулканогенные породы глазуновской свиты (толщи) с габбро-долеритами смородинского комплекса в состав единой вулкано-плутонической ассоциации [4, 5]. С позиции геодинамического анализа В. М. Холин и Ю. Н. Стрик [6] отнесли вулканиты основного состава к поздней стадии рифтогенеза ОрловскоТимской структуры и коррелировали их с базальтами тимской свиты, а вулканиты среднего состава причислили к андезитам орогенных обстановок.

Все вышеперечисленные утверждения основывались на сопоставлении химического состава вулканитов Курского блока с составами эффузивов эталонных геодинамических формаций. Ранее полученный U-Pb изотопный возраст цирконов из андезитовых порфиритов [7] оценивается в $2115 \pm 79$ млн лет, что на настоящий момент не может дать однозначного ответа об их стратиграфическом положении и подтвердить одну из вышеперечисленных схем корреляции.

Цель настоящей статьи - определение U-Pb изо- 


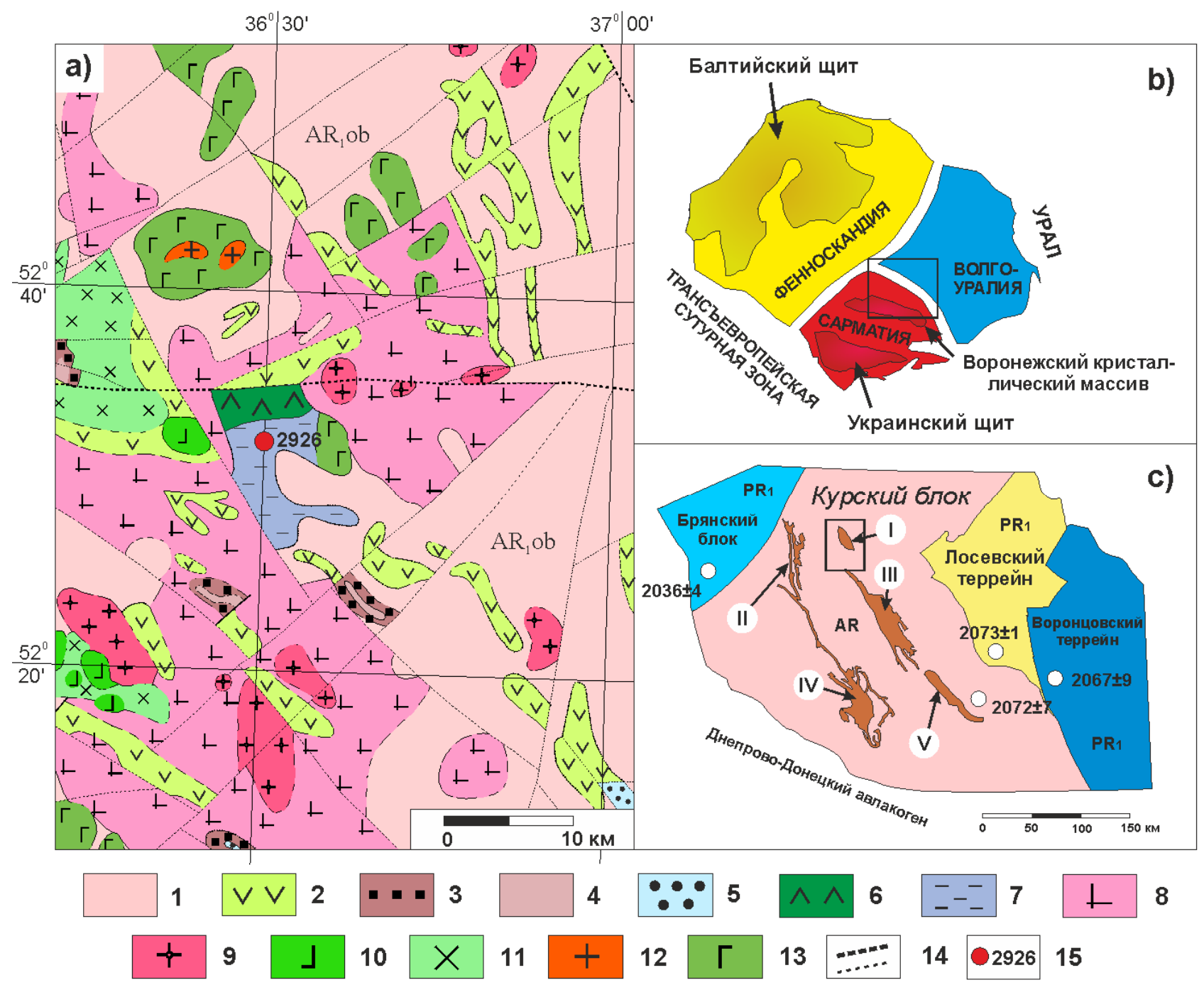

Puc.1. Положение породных комплексов глазуновской свиты в пределах Курского блока Восточной Сарматии: а) схематическая геологическая карта Никитовского участка, b) схема сегментов Восточно-Европейского кратона по [15], с) структурная схема Курского блока, положение в нём структур палеопротерозойского возраста по [16]. Белыми точками обозначен возраст метаморфизма [17]. Условные обозначения к рис. 1a: 1 - обоянский комплекс $\left(\mathrm{AR}_{1} \mathrm{ob}\right) ; 2$ - михайловская серия $\left(\mathrm{AR}_{2} \mathrm{mh}\right) ; 3$ - стойленская свита $\left(\mathrm{PR}_{1} \mathrm{st}\right) ; 4$ - коробковская свита $\left(\mathrm{PR}_{1} \mathrm{kr}\right) ; 5$ - роговская свита $\left(\mathrm{PR}_{1} \mathrm{rg}\right) ; 6$ - тимская свита $\left(\mathrm{PR}_{1} \mathrm{tm}\right) ; 7$ глазуновская свита $\left(\mathrm{PR}_{1} \mathrm{gl}\right) ; 8$ - салтыковский комплекс $\left(p \gamma \mathrm{AR}_{1} \mathrm{sl}\right) ; 9$ - атаманский комплекс $\left(\gamma \mathrm{PR}_{1} \mathrm{at}\right) ; 10$ - золотухинский комплекс $\left(v \mathrm{PR}_{1} \mathrm{z}\right) ; 11$ - стойло-николаевский комплекс $\left(\gamma \delta \mathrm{PR}_{1} \mathrm{sn}\right) ; 12$ - малиновский комплекс $\left(\gamma \mathrm{PR}_{1} \mathrm{ml}\right) ; 13$ - смородинский комплекс $\left(v \mathrm{PR}_{1} \mathrm{sm}\right) ; 14$ - разрывные нарушения различного ранга; 15 - скважины и их номера. Условные обозначения к рис. $1 \mathrm{c}$ : палеопротерозойские синформы КБВС: I - Орловская, II - Михайловская, III - Тим-Ястребовская, IV - Белгородская, V - Волотовская.

топного возраста по цирконам из андезитовых порфиритов глазуновской свиты Курского блока и тектонической обстановки формирования на основе их геохимических признаков.

\section{Геологическая позиция}

Никитовский участок, в пределах которого вскрыты образования глазуновской свиты, расположен в южной части Орловской структуры (ОС), являющейся фрагментом палеопротерозойской Тим-Ястребовской грабен-синклинали. «Рама», обрамляющая Никитовский участок, представлена палеопротерозойскими хемогенно-терригенными метаосадками курской и оскольской серий, несогласно залегающих на архейском фундаменте, большую часть территории которо- го занимают гранито-гнейсы обоянского комплекса, тоналит-трондьемит-гранодиориты салтыковского комплекса и зеленокаменные породы михайловской серии.

Образования глазуновской свиты мощностью 790 метров вскрыты единственной скважиной 2926 (рис. 2). Они несогласно залегают на метабазальтах тимской свиты. В основании глазуновской свиты $\left(\mathrm{PR}_{1} \mathrm{gl}\right)$ имеется пачка конгломерато-брекчий мощностью 53 метра, обломки которых представлены базальтами, базальтовыми метапорфиритами и апобазальтовыми амфиболитами, по минеральному составу и структуре идентичных породам нижней базальтоидной пачки тимской свиты [8]. Выше по разрезу образования свиты представлены тремя пачками пирокластических (туфы, 

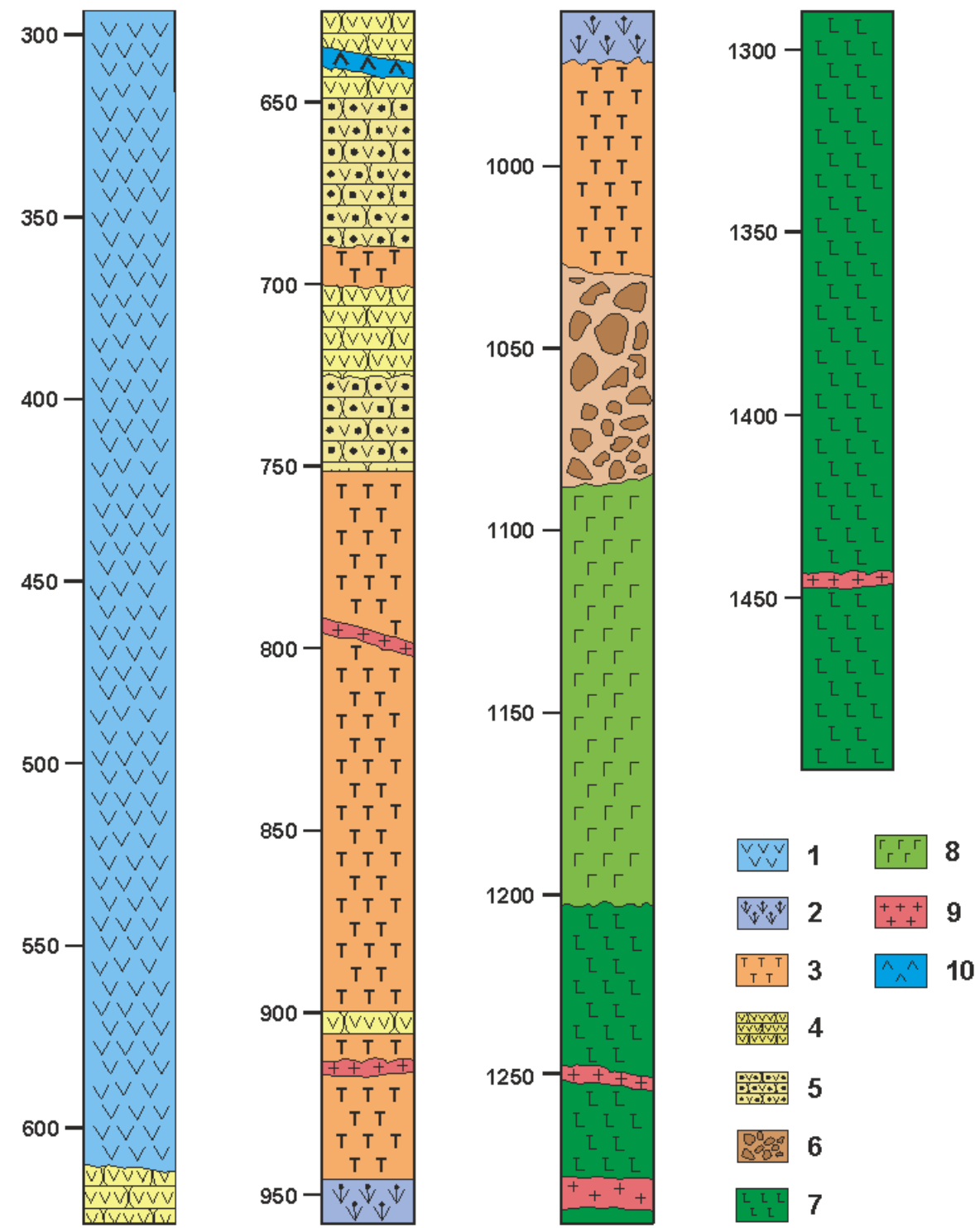

Puc.2. Стратотипический разрез глазуновской свиты (скв. 2926) по [6] с упрощениями. Условные обозначения: 1-6 - образования глазуновской свиты: 1 - андезитовый порфирит, 2 - лавобрекчия андезитового состава, 3 - туфы андезитового состава, 4 - туффиты андезитового состава, 5 - туфоконгломераты, туфогравелиты, 6 - конгломерато-брекчии, 7 - метабазальты, апобазальтовые амфиболиты тимской свиты, 8 - габбро-долериты смородинского комплекса, 9 - дайки гранитов, 10 - дайка микродиоритовых порфиритов.

лавобрекчии андезитовых порфиритов) и туфогенных пород (туффиты, туфогравелиты, туфоконгломераты): нижняя залегает в интервале 1031-903,5 м, средняя пачка - 903,5-750,0 м, верхняя пачка - 750,0-611,6 м. Верхняя часть разреза (около 320 м) сложена субвулканическими породами - андезитовыми порфиритами. Пирокластические и субвулканические образования свиты проявляют сходные петрохимические характеристики [8]. Однако туфы характеризуются бо́льшими вариациями химического состава, что связано с терригенной примесью, поэтому в данной работе мы рассматриваем только субвулканические образования.

\section{Петрография и петрохимия}

Как уже отмечалось выше, субвулканические разновидности глазуновской свиты представлены анде- зитовыми порфиритами.

Андезитовье порфириты представляют собой породы темно-серого цвета, с порфировыми выделениями плагиоклаза размером до 1,5-4 мм. Их количество колеблется от 30 до $80 \%$, в среднем составляет $50 \%$. Под микроскопом породы имеют полифировую структуру. Вкрапленники представлены резко доминирующим нередко зональным плагиоклазом (30-80 \%) и амфиболом (до 15 \%). Обычно вкрапленники расположены беспорядочно, но иногда ориентированы в одном направлении, образуя директивную текстуру. Центральные части зональных плагиоклазов представлены лабрадором $\left(\mathrm{An}_{56-62}\right)$, краевые - андезином $\left(\mathrm{An}_{32-37}\right)$. Амфибол образует зёрна размером от 0,2 до 1,5 мм, зелёного до сине-зеленого цвета и диагностируется как магнезиальная роговая обманка $(\mathrm{Si}=6,5-7,0$; 
$\left.\mathrm{Mg} / \mathrm{Mg}+\mathrm{Fe}^{2+}=0,6-0,7\right)$, иногда по периферии кристаллов роговой обманки наблюдаются выделения магнетита, образующего рудную оторочку (рис. 3). Основная масса (до $55 \%$ ), выполняющая промежутки между зернами плагиоклазов и амфиболов сложена калишпаткварц-плагиоклазовым агрегатом с примесью биотита, амфибола, эпидота и представляет собой тонкомелкозернистую основную ткань. Акцессорные мине- ралы представлены цирконом, апатитом, магнетитом.

Андезитовые порфириты характеризуются содержанием $\mathrm{SiO}_{2}=57-61$ \% и повышенной магнезиально-

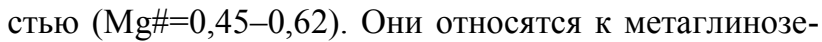
мистым калиево-натровым $\left(\mathrm{Na}_{2} \mathrm{O} / \mathrm{K}_{2} \mathrm{O}=1,1-3,2\right)$ породам. По соотношению $\mathrm{K}_{2} \mathrm{O}-\mathrm{SiO}_{2}$ порфириты являются высококалиевыми разностями щелочно-известковистой серии (рис. 4 а-г).
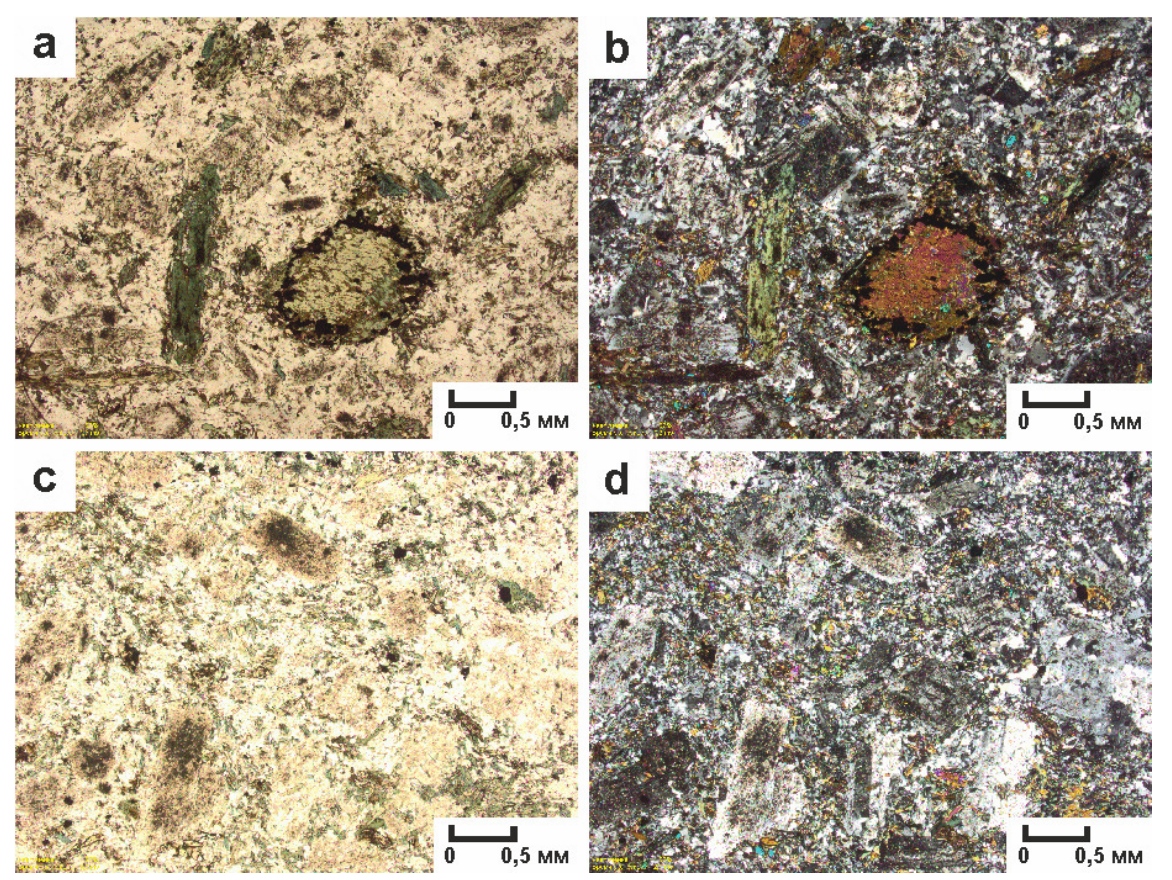

Рис. 3. Фото шлифов андезитовых порфиритов: $a$, $b$ - обр. 2926/402, c, $d$ - обр. 2926/443. Слева без анализатора, справа с анализатором.
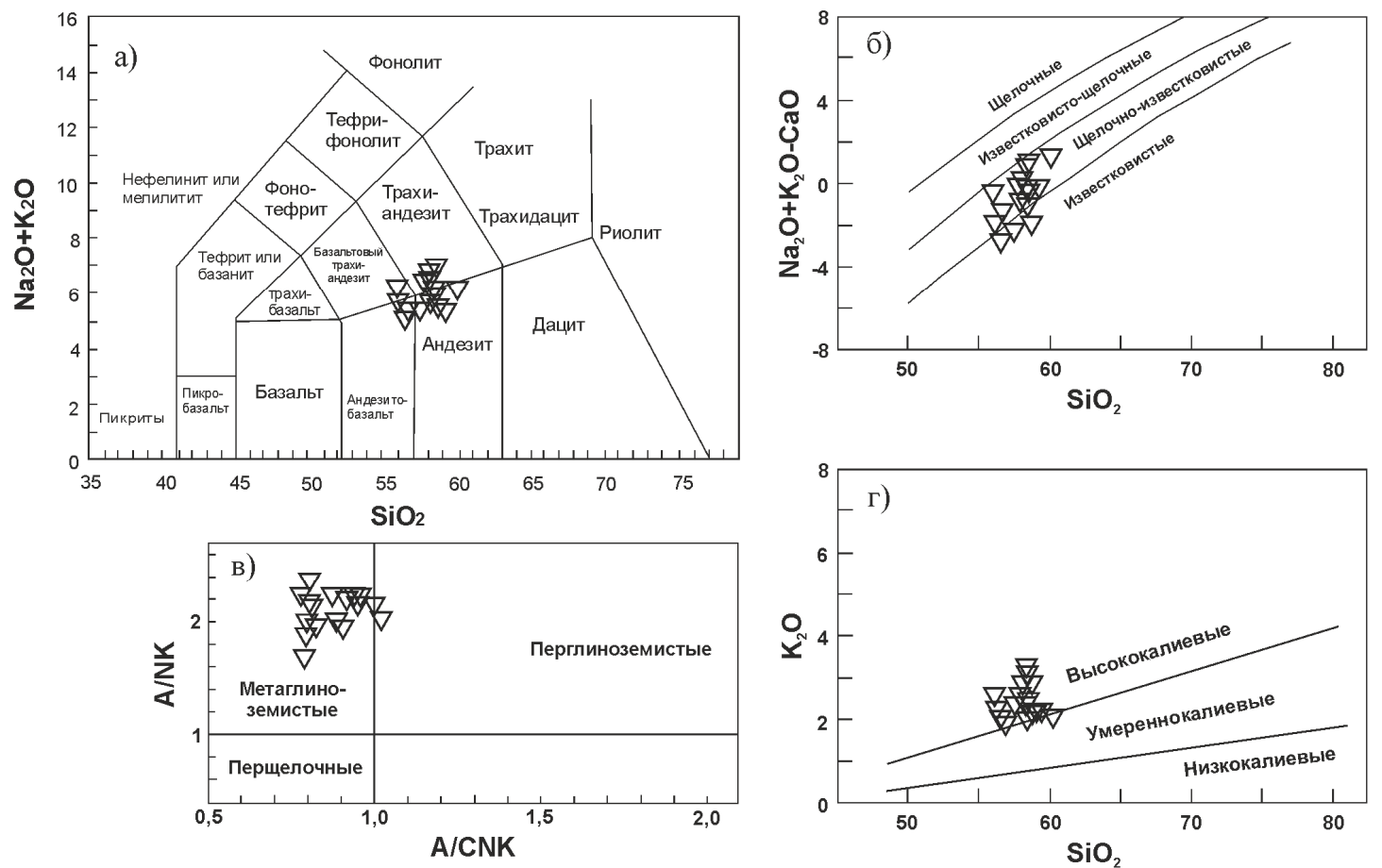

Puc.4. Составы вулканитов глазуновской свиты на классификационных диаграммах: а) TAS [18]; б) $\mathrm{Na}_{2} \mathrm{O}+\mathrm{K}_{2} \mathrm{O}-\mathrm{CaO}-\mathrm{Si}_{2} \mathrm{O}$ [19]; в) A/NK (в молекулярных количествах $\mathrm{Al}_{2} \mathrm{O}_{3} /\left(\mathrm{Na}_{2} \mathrm{O}+\mathrm{K}_{2} \mathrm{O}\right)$ )-A/CNK (в молекулярных количествах $\mathrm{Al}_{2} \mathrm{O}_{3} /\left(\mathrm{CaO}_{2}-\mathrm{Na}_{2} \mathrm{O}+\mathrm{K}_{2} \mathrm{O}\right)$ ) [20]; г) $\mathrm{K}_{2} \mathrm{O}-\mathrm{SiO}_{2}[21]$. 


\section{U-Pb изотопный возраст}

Измерения абсолютного возраста цирконов из андезитовых порфиритов глазуновской свиты (обр. 2926/449,6) выполнены с помощью мультиколлекторного вторично-ионного масс-спектрометра высокого разрешения SHRIMP-II в Центре изотопных исследований ВСЕГЕИ, г. Санкт-Петербург, по стандартной методике [9, 10] с использованием эталонных цирконов «91500» и «Теmora». При расчетах использовали константы распада, предложенные в работе [11], и вводили поправку на нерадиогенный свинец по [12] на основе измеренного отношения ${ }^{204} \mathrm{~Pb} /{ }^{206} \mathrm{~Pb}$. Полученные результаты обрабатывали с помощью программ «SQUID v1.12» и «ISOPLOT/Ex 3.22» [13, 14].
Цирконы из андезитовых порфиритов представлены субидиоморфными, редко идиоморфными короткопризматическими кристаллами и их обломками размером до 200-400 мкм (рис. 5). Цирконы прозрачные и полупрозрачные, а в зонах, содержащих включения других минеральных фаз и трещины, приобретают светло-коричневую от слабой до насыщенной окраску. В катодной люминесценции в цирконах отмечается осцилляционная концентрическая зональность, что предполагает их исходную магматическую природу.

Результаты изотопного датирования приведены на рис. 6 и в табл. 1. Возраст андезитовых порфиритов по верхнему пересечению с конкордией оценивается как $2074 \pm 12$ млн лет. Однако, согласно общемировой
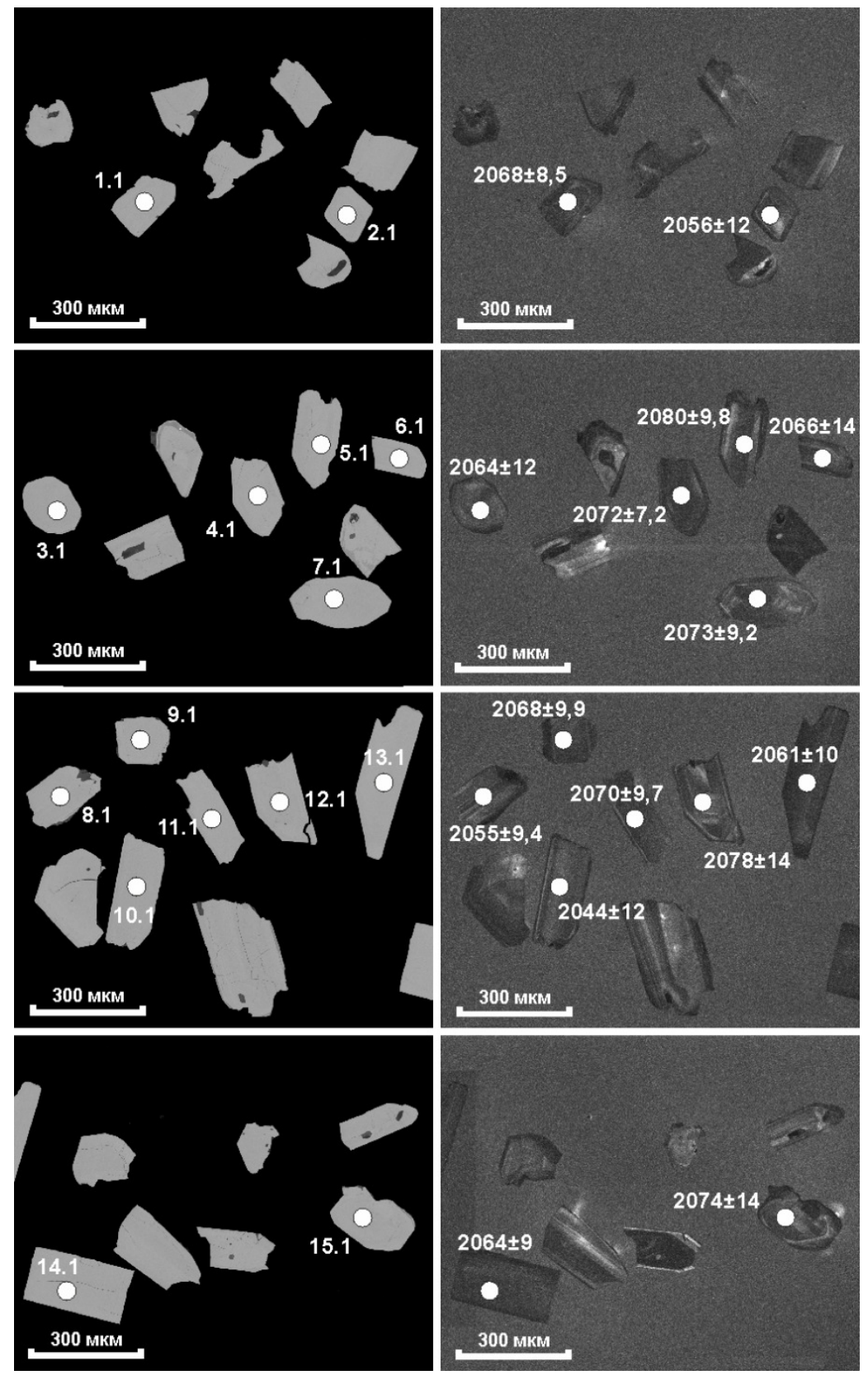

Puc.5. Изображения цирконов из андезитовых порфиритов глазуновской свиты (обр.2926/449,6). Слева - снимки в отраженном свете; справа - в катодной люминесценции. Точками отмечены места U-Pb изотопных исследований и значения возрастов $\left({ }^{207} \mathrm{~Pb} /{ }^{206} \mathrm{~Pb}\right)$ в млн лет. 
практике обработки результатов U-Pb исследований, выполненных локальными методами, приоритетным в качестве оценки возраста докембрийских цирконов считаются средние величины возраста $\left({ }^{207} \mathrm{~Pb} /{ }^{206} \mathrm{~Pb}\right)$. Средневзвешенный ${ }^{207} \mathrm{~Pb} /{ }^{206} \mathrm{~Pb}$ возраст цирконов из андезитовых порфиритов составил $2067 \pm 5$ млн лет.
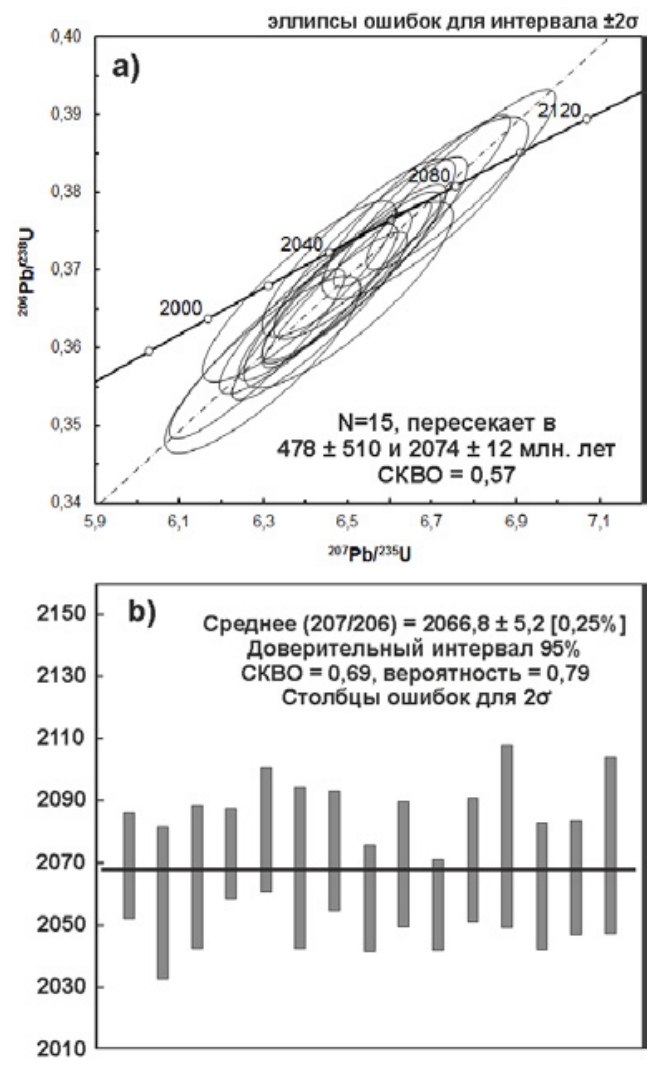

Puc.6. Результаты изотопного датирования цирконов из андезитовых порфиритов глазуновской свиты КБВС.

\section{Тектоническая позиция}

Полученные значения возраста цирконов из андезитовых порфиритов «моложе» пика коллизионного события, зафиксированного в восточной части Курского блока и маркируемого региональным метаморфизмом с возрастом $2072 \pm 7$ млн лет [17]. Данное обстоятельство позволяет говорить о формировании породной ассоциации глазуновской свиты на постколлизионном этапе развития коры. В пользу чего выступает положение точек составов андезитовых порфиритов на дискриминантной диаграмме, используемой для определения геодинамической обстановки формирования средних пород [22] (рис. 7).

\section{Выводы}

Неоднозначная трактовка тектонических условий формирования докембрийских вулканитов в пределах Курского блока, связана как с «закрытостью» территории осадочным чехлом, что делает недоступным её для прямого изучения, так и с отсутствием прецизионных датировок. Полученные нами изотопные данные позволили установить положение андезитовых

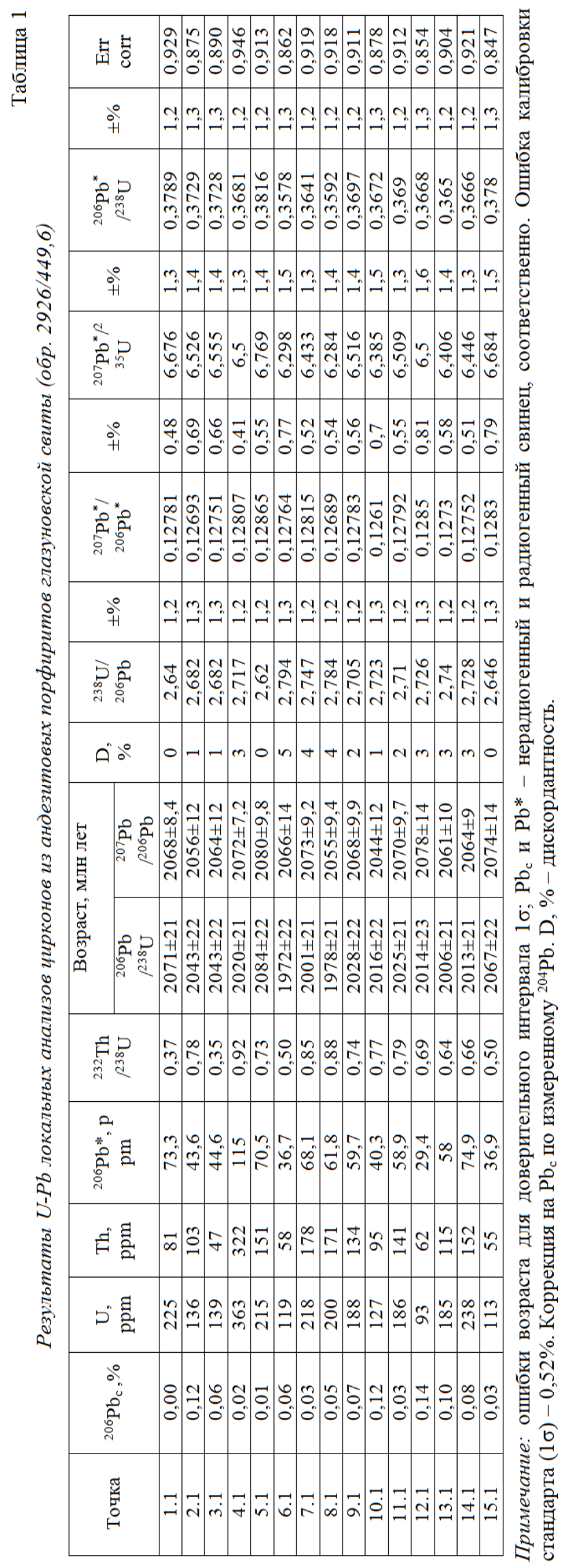

ВЕСТНИК ВГУ. СЕРИЯ: ГЕОЛОГИЯ. 2018. № 3 


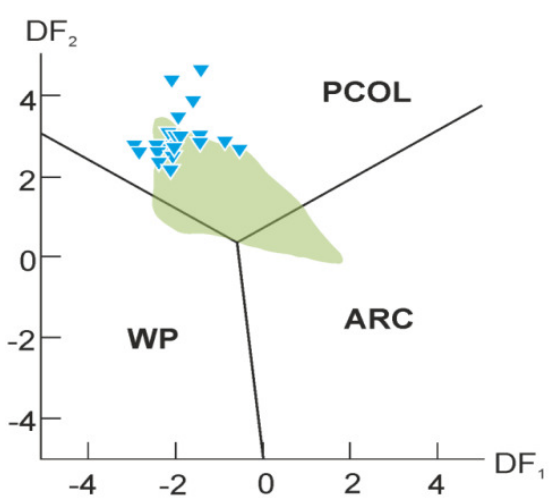

Pис.7. Дискриминантная диаграмма для андезитов глазуновской свиты [22]. Треугольники - составы андезитовых порфиритов, поле - составы андезитовых туфов по [6]. Поля андезитов: ARC - островных дуг, WP - внутриплитных и PCOL - постколлизионных обстановок.

$\mathrm{DF} 1=-2,45605 \ln \left(\mathrm{TiO}_{2} / \mathrm{SiO}_{2}\right)+1,11985 \ln \left(\mathrm{Al}_{2} \mathrm{O}_{3} / \mathrm{SiO}_{2}\right)-$ $2,22475 \ln \left(\mathrm{Fe}_{2} \mathrm{O}_{3} / \mathrm{SiO}_{2}\right)+2,48861 \ln \left(\mathrm{FeO} / \mathrm{SiO}_{2}\right)-$ $0,212024 \ln \left(\mathrm{MnO} / \mathrm{SiO}_{2}\right)-0,06661 \ln \left(\mathrm{MgO} / \mathrm{SiO}_{2}\right)+$ $\left.1,29066 \ln \mathrm{CaO} / \mathrm{SiO}_{2}\right)-0,28377 \ln \left(\mathrm{Na}_{2} \mathrm{O} / \mathrm{SiO}_{2}\right)-$ $0,40211 \ln \left(\mathrm{K}_{2} \mathrm{O} / \mathrm{SiO}_{2}\right)+0,030635 \ln \left(\mathrm{P}_{2} \mathrm{O}_{5} / \mathrm{SiO}_{2}\right)-11,43097347$

$\mathrm{DF} 2=-0,57759 \ln \left(\mathrm{TiO}_{2} / \mathrm{SiO}_{2}\right)-0,01121 \ln \left(\mathrm{Al}_{2} \mathrm{O}_{3} / \mathrm{SiO}_{2}\right)+$ $0,69125 \ln \left(\mathrm{Fe}_{2} \mathrm{O}_{3} / \mathrm{SiO}_{2}\right)-1,99798 \ln \left(\mathrm{FeO} / \mathrm{SiO}_{2}\right)-$

$1,72014 \ln \left(\mathrm{MnO} / \mathrm{SiO}_{2}\right)+0,305275 \ln \left(\mathrm{MgO} / \mathrm{SiO}_{2}\right)+$

$\left.0,816018 \ln \mathrm{CaO} / \mathrm{SiO}_{2}\right)-1,791727 \ln \left(\mathrm{Na}_{2} \mathrm{O} / \mathrm{SiO}_{2}\right)+$

$0,871298 \ln \left(\mathrm{K}_{2} \mathrm{O} /{ }_{\mathrm{SiO} 2}\right)+0,335479 \ln \left(\mathrm{P}_{2} \mathrm{O}_{5} / \mathrm{SiO}_{2}\right)-12,20158596$

порфиритов в стратиграфической схеме Курского блока Восточной Сарматии и определить геодинамическую обстановку формирования как постколлизионную.

\section{Благодарности}

Авторы благодарны Ю. Н. Стрику и В. М. Холину за ценные консультации при написании настоящей статьи. Исследование выполнено при финансовой поддержке РФФИ в рамках научного проекта № 18-35-00058.

\section{ЛИТЕРАТУРА}

1. Крестин, E. М. Вулканизм нижнего протерозоя Курско-Воронежского кристаллического массива / Е.М. Крестин // Вулканизм докембрия (материалы Второго Всесоюзного палеовулканического симпозиума). - Петрозаводск. - 1976. - С. 111-118.

2. Быков, И. Н. Некоторые аспекты петрогенеза раннепротерозойской андезитовой серии северной части Воронежского кристаллического массива/ И. Н. Быков, Ю. Н. Стрик // Тез. Докл. VII симп. по геохимии магматических пород. - 1981. - С.16.

3. Быков, И. Н. Рудные минералы вулканитов трапповой и андезитовой формаций раннего протерозоя северной части КМА / И. Н. Быков, Т. П. Коробкина // Деп. в ВИНИТИ № 2224-83. - Воронеж. - 1983. - 117 c.

4. Чернышов, H. M. Вулкано-плутоническая ассоциация основных пород позднего докембрия КМА / Н. М. Чернышов, В. Л. Бочаров, В. С. Чесноков // Вопросы петрологии и рудоносности основного-ультраосновного магматизма Воронежского кристаллического массива. - Воронеж. - 1974. - С. 26-31.

\section{Воронежский государственный университет}

Савко Константин Аркадиевич, д. г.-м. н., профессор, заведующиии кафедрой полезных ископаемых и недропользования E-mail: ksavko@geol.vsu.ru; Тел.: 8-915-544-21-64 Цыбуляев Сергей Владимирович, аспирант кафедры полезных ископаемых и недропользования.

E-mail: stsybulyaev@bk.ru; Тел.: 8-930-408-88-91
5. Чернышов, Н. М. Траппы Курской магнитной аномалии. / Н. М. Чернышов, В. С. Чесноков // - Воронеж: Изд-во Воронеж. ун-та. $-1983 .-276$ с

6. Холин, В. М. О соотношении базальтового и андезитового вулканизма глазуновской свиты КМА / В. М. Холин, Ю. Н. Стрик // Вестник Воронеж. гос. ун-та. Сер.: Геология. - 2000. № 5 (10). - C. 115-120.

7. Артеменко, Г. В. Геохронологическая корреляция вулканизма и гранитоидного магматизма юго-восточной части Украинского щита и Курской магнитной аномалии / Г. В. Артеменко // Геохимия и рудообразование. - 1995. - Вып. 21. C. $129-142$.

8. Холин, В. М. Геология, геодинамика и металлогеническая оценка раннепротерозойских структур КМА: автореф. дисс. канд. геол.-мин. наук / В. М. Холин. - Воронеж. $-2001 .-24$ с.

9. Williams, I. S. U-Th-Pb Geochronology by ion microprobe / I. S. Williams // Applications in micro analytical techniques to understanding mineralizing processes. - Rev. Econ. Geol. - 1998. V. 7. - P. 1-35.

10. Larionov, A. N. The Vendian alkaline igneous suite of northern Timan: ion microprobe $\mathrm{U}-\mathrm{Pb}$ zircon ages of gabbros and syenite / A. N. Larionov, V. A. Andreichev, D. G. Gee // Gee D. G., Pease V. L. (Eds.). The Neoproterozoic Timanide Orogen of Eastern Baltica. Geological Society London Memoirs. - 2004. - V. 30. - P. 69-74.

11. Steiger, R. H. Subcommission on geochronology: convention of the ust of decay constants in geo- and cosmochronology / R. H. Steiger, E. Jäger // Earth Planet. Sci. Lett. - 1977. - V. 36. - P. 359-362.

12. Stacey, J. S. Approximation of terrestrial lead isotope evolution by a twostage model / J.S. Stacey, J.D. Kramers // Earth Planet. Sci. Lett. - 1975. - V . 26. - P. 207-221.

13. Ludwig, K. R. SQUID 1.12 A User's Manual. A Geochronological Toolkit for Microsoft Excel / K. R. Ludwig // Berkeley Geochronology Center Special Publication. - 2005. -22 p.

14. Ludwig, K. R. Isoplot. Ex ver. 3.6. / K.R. Ludwig // Berkeley Geochronology Center Special Publications, 2008. - № 4. - 77 p.

15. Gorbatschev, R. Frontiers in the Baltic Shield / R. Gorbatschev, S. Bogdanova // Precambrian Res. - 1993. - V. 64. - P. 3-21.

16. Савко, К. А. Мегаблок Сарматия как осколок суперкратона Ваалбара: корреляция геологических событий на границе архея и палеопротерозоя / К. А. Савко, А. В. Самсонов, В. М. Холин, Н. С. Базиков // Стратиграфия. Геологическая корреляция. 2017. - T. 25. - № 2. - C. 3-26.

17. The Early Precambrian metamorphic events in Eastern Sarmatia / K. A. Savko [et al.] // Precambrian Res. - 2018. - V. 301 - P. 1-23.

18. Igneous Rocks: A Classification and Glossary of Terms, Recommendations of the International Union of Geological Sciences, Subcommission of the Systematics of Igneous Rocks. / R.W. Le Maitre [et al.] // Cambridge University Press. - 2002. -236 p.

19. A geochemical classification for granitic rocks / B. R. Frost [et al.] // Journal of Petrology - 2001. - V. 42. - P. 2033-2048.

20. Maniar, P. D. Tectonic discrimination of granitoids / P. D. Maniar, P. M. Piccoli // Geol. Soc. Am. Bull. - 1989. - V. 101 - P. 636-643.

21. Rickwood, P. C. Boundary lines within petrologic diagrams, which use oxides of major and minor elements / P. C. Rickwood // Lithos. - 1989. - V. 22. - P. 247-263.

22. Verma, S. P. First 15 probability-based multidimensional tectonic discrimination diagrams for intermediate magmas and their robustness against postemplacement compositional changes and petrogenetic processes / S. P. Verma, S. K. Verma // Turkish Journal of Earth Sciences. - 2013. - V. 22. - № 6. - P. 931-995

\section{Voronezh State University}

Savko K. A., Doctor of Geologicial and Mineralogical Sciences, Professor, Head of the Mineral Resource Department

E-mail: ksavko@geol.vsu.ru; Tel.: 8-915-544-21-64

Tsybulyaev S.V., Postgraduate of the Mineral Resource Department

E-mail: stsybulyaev@bk.ru; Tel.: 8-930-408-88-91 